\title{
Changing indications for paediatric tracheostomy and the role of a
} multidisciplinary tracheostomy clinic - ERRATUM

M M C YANEZA, H L JAMES, P DAVIES, S HARRISON, L MCALORUM, W A CLEMENT, H KUBBA

doi:10.1017/S0022215115001140, Published by Cambridge University Press, September 2015, pages 882-886.

This paper was published with the author's name showing as HP James. This should have read HL James.

Reference

1 Yaneza MMC, James HL, Davies P, Harrison S, McAlorum L, Clement WA, Kubba H. Changing indications for paediatric tracheostomy and the role of a multidisciplinary tracheostomy clinic. J Laryngol Otol 2015;129:882-6 